\title{
Glaciological observations of Brúarjökull, Iceland, using synthetic aperture radar and thematic mapper satellite data
}

\author{
Dorothy K. HaLl, \\ NASA/Goddard Space Flight Center, Code 974, Greenbelt, MD 20771, U.S.A. \\ RichaRd S. Williams, JR, \\ U.S. Geological Survey, Quissett Campus, Woods Hole, MA 02543, U.S.A. \\ Oddur SigurdsSON \\ National Energy Authority, Grensásvegi 9, IS-108 Reykjavik, Iceland
}

\begin{abstract}
The first European Remote Sensing Satellite (ERS-1) synthetic aperture radar (SAR) images offer opportunities for studying glacier surface properties and near-surface features. Analysis of back-scatter values from digital SAR data from 18 January, 7 June, 1 September and 25 October 1993 of Brúarjökull, an outlet glacier on the northeastern margin of the Vatnajökull ice cap, Iceland, that has a history of episodic surges, reveals several back-scatter boundaries that may relate to glacier facies and, inferentially, to mass balance. For example, a strong back-scatter boundary on the 18 January image of the snow-covered glacier, representing a back-scatter coefficient, $\sigma^{\circ}$, difference of $4.34 \mathrm{~dB}$, appears to coincide with the position of the transient snow line at the end of the 199091 budget year. The boundary is visible on the 7 September 1991 Landsat thematic mapper (TM) image. The terminus is very difficult to define because of back-wasting from the last surge (1963-64) but is most easily delineated on the 1 September 1993 SAR and the 7 September 1991 TM images, in part due to the presence of ice-margin lakes.
\end{abstract}

\section{INTRODUCTION}

Changes in ice caps (and their outlet glaciers) and valley and mountain glaciers may be good indicators of regional climate change if studied over a decadal time-scale, because smaller glaciers respond to changes in regional climate on a scale of decades (Hall and others, 1992; Oerlemans, 1994). During this century, many of the world's valley and mountain glaciers and ice caps have been receding (Meier, 1985; Haeberli and others, 1989), although some advances have occurred during intervals of cooling (Wood, 1988; Sigurdsson and Jónsson, 1995) or because of periodic surges. Meier (1984) suggested that the reduction in mass of the smaller glaciers has contributed at least one-third of the total rise in global sea level during this century. Oerlemans (1994) suggests through the modeling of glaciers that the observed glacier retreat can be explained by a linear warming trend of $0.66^{\circ} \mathrm{C}$ per century.

Beginning with the launch of the Seasat L-band $(1.3 \mathrm{GHz})$ synthetic aperture radar (SAR) in 1978, and continuing with the 1991 launch of the first European Remote Sensing Satellite (ERS-1) C-band $(5.3 \mathrm{GHz})$ SAR and the 1992 launch of the L-band Japanese Earth Resources Satellite-1 (JERS-1) SAR, satellite-borne radars have been used to make glaciological measure- ments. The use of SAR and Landsat multispectral scanner (MSS) and thematic mapper (TM)) satellite data together provides a useful means of studying glaciers (Hall and Ormsby, 1983). Because these sensors may sense different surface and sub-surface glaciological features, more information can be gained through analysis of data from both sensors than from a single sensor.

The present study concerns the use of ERS-1 and Landsat TM data for the study of glaciological features on the surface and sub-surface of Brúarjökull, an outlet glacier that has a history of episodic surges, on the northeastern margin of the Vatnajökull ice cap, Iceland. A time series of satellite data reveals information that may relate to glacier facies and, inferentially, to mass balance.

\section{PREVIOUS STUDIES}

Landsat images have been used throughout the past 20 years to study Iceland's glaciers, including measuring changes in the termini of outlet glaciers (from ice caps) resulting from changes in mass balance or surge behavior (Williams and others, 1974; Williams, 1983; Hall and others, 1992). A Landsat MSS image and a 1986 Landsat TM image, which were analyzed by Williams (1987) and Williams and others (1991), respectively, provided 
information on the position of the snow line, the ice facies of the ablation area and the wet-snow facies of the accumulation area.

Satellite SAR studies of Iceland's glaciers have also been carried out. Ford and others (1980) published a cursory analysis of a Seasat SAR image (August 1978) and of a companion Landsat MSS image (May 1976) that included part of the Dyngjujökull and Kverkjökull outlet glaciers on the north-central margin of the Vatnajökull ice cap. Rott (1984a) analyzed a 24 August 1978 Seasat SAR image of Hofsjökull, an ice cap $\left(915 \mathrm{~km}^{2}\right)$ about $30 \mathrm{~km}$ northwest of Vatnajökull. He found that low back-scatter characterized the wet-snow facies on the ice cap, and that back-scatter increased down-glacier on the summer scene (Rott 1984b). Using a Seasat SAR mosaic (August 1978) of Iceland compiled by Hunting Geology and Geophysics, Ltd. (no date), Williams (1987) found that some surface features on Vatnajökull were strongly portrayed (e.g. two calderas at Kverkfjöll), but other prominent features were not (e.g. Grímsvotn caldera).

Bindschadler and others (1987) found that surface features (e.g. ice-flow lines, undulations, crevasses, lakes) and sub-surface features (e.g. boundaries that may relate to glacier facies) were visible on both Seasat SAR data and side-looking airborne radar (SLAR) data of the Greenland ice sheet. Recently, Fahnestock and others
(1993) found that back-scatter boundaries on ERS-1 SAR data compared well with the position of the glacier facies mapped during Benson's traverses of the Greenland ice sheet in the 1950s (Benson, 1962). Lingle and others (1992) showed that the presumed late-summer snow line was visible through the winter snowpack on ERS-1 SAR data of the Black Rapids Glacier, Alaska, when surface water was frozen, and the dry snow is transparent, or nearly transparent to the ERS-1 SAR signal.

\section{SATELLITE SENSORS AND IMAGE DATA USED IN THE ANALYSIS OF BRÚARJÖKULL}

The MSS was first launched on the Landsat 1 satellite in 1972. Five Landsat satellites have been orbited thus far; only Landsat 5 is still providing image data. The Landsat TM sensor was first launched in 1982. The TM produces images in seven discrete wavelength regions of the electromagnetic spectrum. Landsat 5 has a repeat cycle of $16 \mathrm{~d}$, but many areas are imaged much less frequently because of cloud cover. The ERS-1 carries a SAR that operates in three phases: a $3 \mathrm{~d}$ repeat commissioning phase, a $3 \mathrm{~d}$ repeat ice phase, and a $35 \mathrm{~d}$ repeat multidisciplinary phase (ESA, 1993). Image data used in the analysis of Brúarjökull (Fig. 1) are a Landsat TM scene (Fig. 2) acquired on 7 September 1991 (52746-

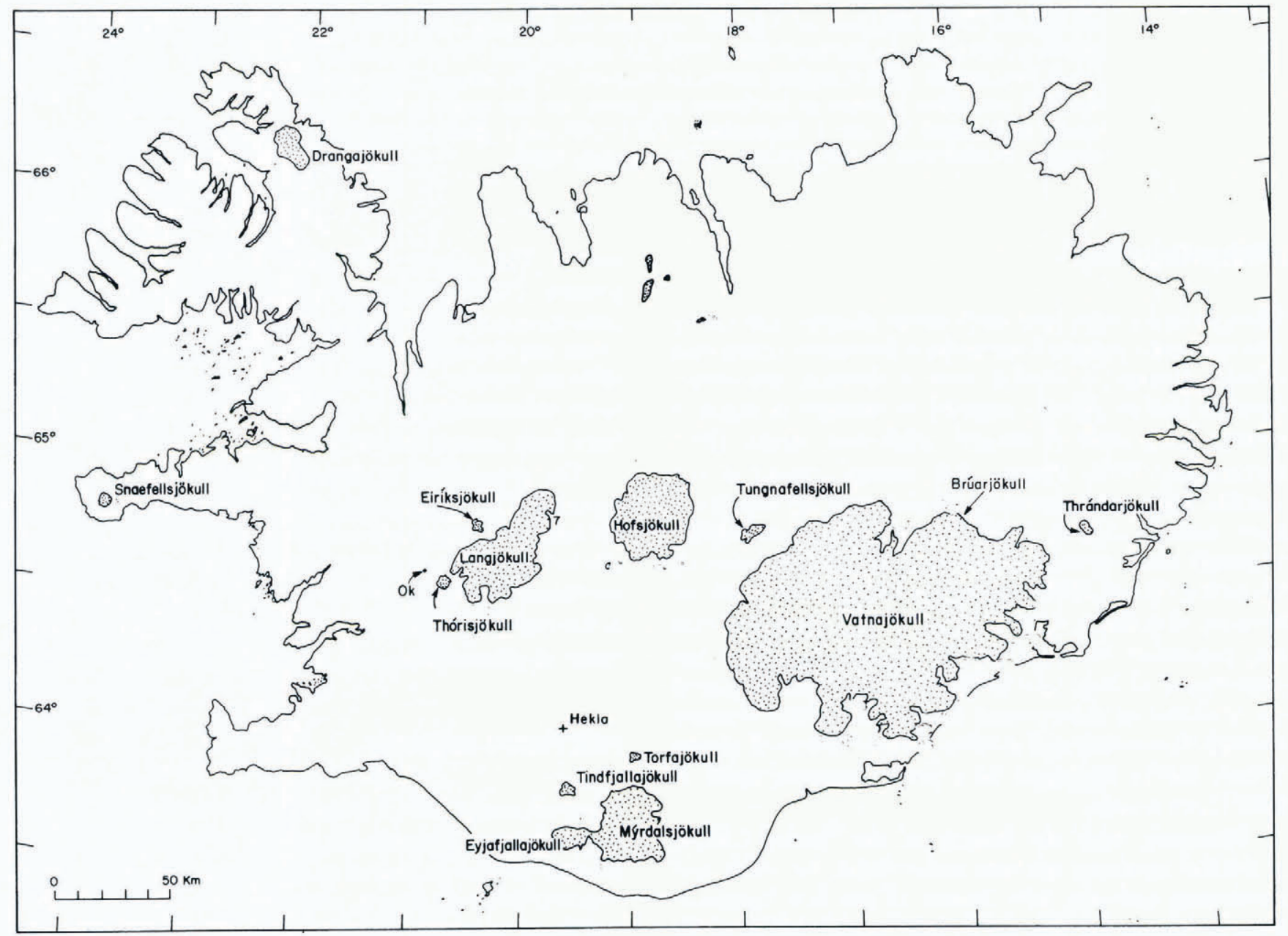

Fig. 1. Index map showing the principal glaciers in Iceland, including the location of the Briarjökull outlet glacier in the northeastern part of Vatnajökull ice cap. 


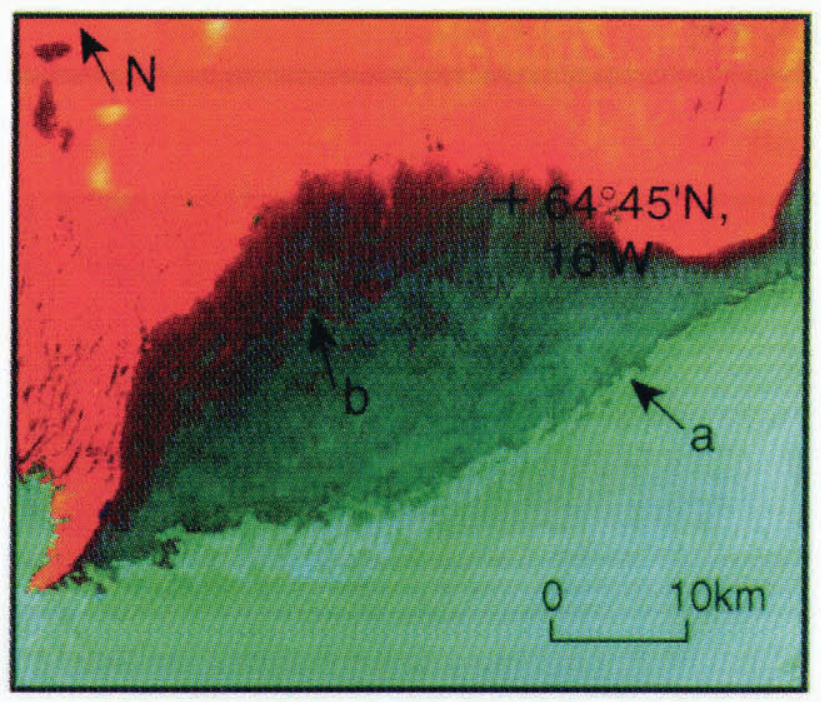

7 September 1991

Fig. 2. Landsat TM sub-scene (52746-11513) of the Bruarjökull outlet glacier of the Vatnajökull ice cap, Iceland, on 7 September 1991. TM bands 2 (0.52 $0.6 \mu \mathrm{m}), 4(0.760 .9 \mu \mathrm{m})$, and $5(1.551 .75 \mu \mathrm{m})$ were used to create this false-color image. The position of the firn line is indicated by a reflectance difference as shown at the arrow at $a$. At b, the arrow points to one of the tephra layers.

11513 and four ERS-1 SAR images acquired in the winter (18 January), spring ( 7 June), summer (1 September) and fall (25 October) of 1993 (Fig. 3A-D).

\section{CALGULATION OF ERS-1 SAR BACK-SGATTER COEFFICIENT}

In order to perform quantitative studies, ERS-1 SAR pixel values (digital numbers) must be related to backscatter coefficient, $\sigma^{\circ}$ (Laur, 1992). The relationship between image intensity, $I$, and $\sigma^{\circ}$ is:

$$
\langle I\rangle=K \sigma^{\circ}
$$

where $\langle I\rangle$ is the mean pixel image intensity of no less than 500 pixels and $K$ is the constant of proportionality, or calibration constant.

SAR image data of Brúarjökull (Fig. 3 ) represent the ERS-1 Precision Image (PRI) data product generated at the Processing and Archiving Facility in the U.K. This is the ESA standard product for SAR radiometric-precision analysis. Calibration constants are time-dependent, but because of the high radiometric stability of the ERS-1 SAR, the constant remained the same during the study period. $K$ is dependent upon incidence angle, $\alpha$, arising from the physical projection of the satellite-system transfer function upon the imaged surface. $K$ is valid for one product and one SAR processor only. $K$ is determined as 890107.2 scalar or $59.49 \mathrm{~dB}$ for products processed after 1 September 1992

To determine a back-scatter coefficient accurately from each selected site, the local incidence angle must be determined. PRI SAR incidence angles usually vary from $19.5^{\circ}$ at near range to $26.6^{\circ}$ at far range. This $7.1 \mathrm{~dB}$ spread, or $\pm 3.55^{\circ}$ from scene center, was interpolated linearly along the entire 8200 pixel spread for the image. After each site's local incidence angle was determined, the site itself was extracted as a $64 \times 64$ pixel image or a $32 \times 32$ pixel sub-image.

To derive the local estimate of the calibration constant, $K(\alpha)$, the following equation is applied:

$$
K(\alpha)=K \sin \frac{\alpha_{\text {ref }}}{\sin \alpha}
$$

where $\alpha_{\text {ref }}$ is the reference incidence angle, and $\sigma=23^{\circ}$, which is the mid-range incidence angle; therefore, the value, $K$, in ESA SAR products is:

$$
K=K\left(\alpha_{\text {ref }}=23^{\circ}\right)
$$

$\langle I\rangle$ was determined for the sub-image by:

$$
\langle I\rangle=1 / N \sum_{i=1}^{N} D_{i}{ }^{2}
$$

where $N$ is a large pixel number $(>500)$ to ensure statistical validity of the estimation of mean intensity, and $D_{i}$ is the digital number of a given pixel, $i$, and is proportional to the square root of $I$ received from the ground-resolution cell corresponding to pixel $i$.

The back-scatter $\left(\sigma^{\circ}\right)$ value expressed in $\mathrm{dB}$ may be calculated as follows (Laur 1992):

$$
\begin{aligned}
\sigma^{\mathrm{o}}(\mathrm{dB})=\left(10 \log _{10}\langle I\rangle\right) & -\left[\left(10 \log _{10} K\right)\right. \\
& \left.+\left(10 \log _{10} \frac{\sin \alpha}{\sin \alpha_{\mathrm{ref}}}\right)\right]
\end{aligned}
$$

\section{GEOLOGIC HISTORY AND SETTING OF BRÚARJÖKULL}

Brúarjökull is a broad, gently sloping, lobate outlet glacier on the northeastern margin of the Vatnajökull ice cap, Iceland, with a margin of about $45 \mathrm{~km}$ that experiences episodic surges. Brúarjökull has the longest recorded history of surges known in Iceland, with five documented (1625, the 1720s, 1810, 1890 and 1963-64); it also experiences the largest surges in terms of area of glacier affected $\left(1400 \mathrm{~km}^{2}\right)$ and advance $(10 \mathrm{~km}$ in 1890 , $8 \mathrm{~km}$ in 1963-64) (Todtmann, 1960; Thorarinsson, 1964). In the ablation zone of Brúarjökull, many semi-concentric contorted layers of tephra are moving with the ice flow towards the terminus.

\section{ANALYSIS OF THE ERS-1 SAR IMAGES AND THE LANDSAT TM IMAGE}

The ERS-1 SAR image acquired on 18 January 1993 is shown in Figure 3A. A boundary delineating different back-scatter intensities can be seen clearly at the arrow. Back-scatter values are higher at higher elevations (toward the south), where $\sigma^{\circ}$ is approximately $-2.53 \mathrm{~dB}$, than at lower elevations (toward the north), where $\sigma^{\circ}=-6.87 \mathrm{~dB}$. Of particular interest is the fact that this back-scatter 


\section{ERS - 1 SAR}

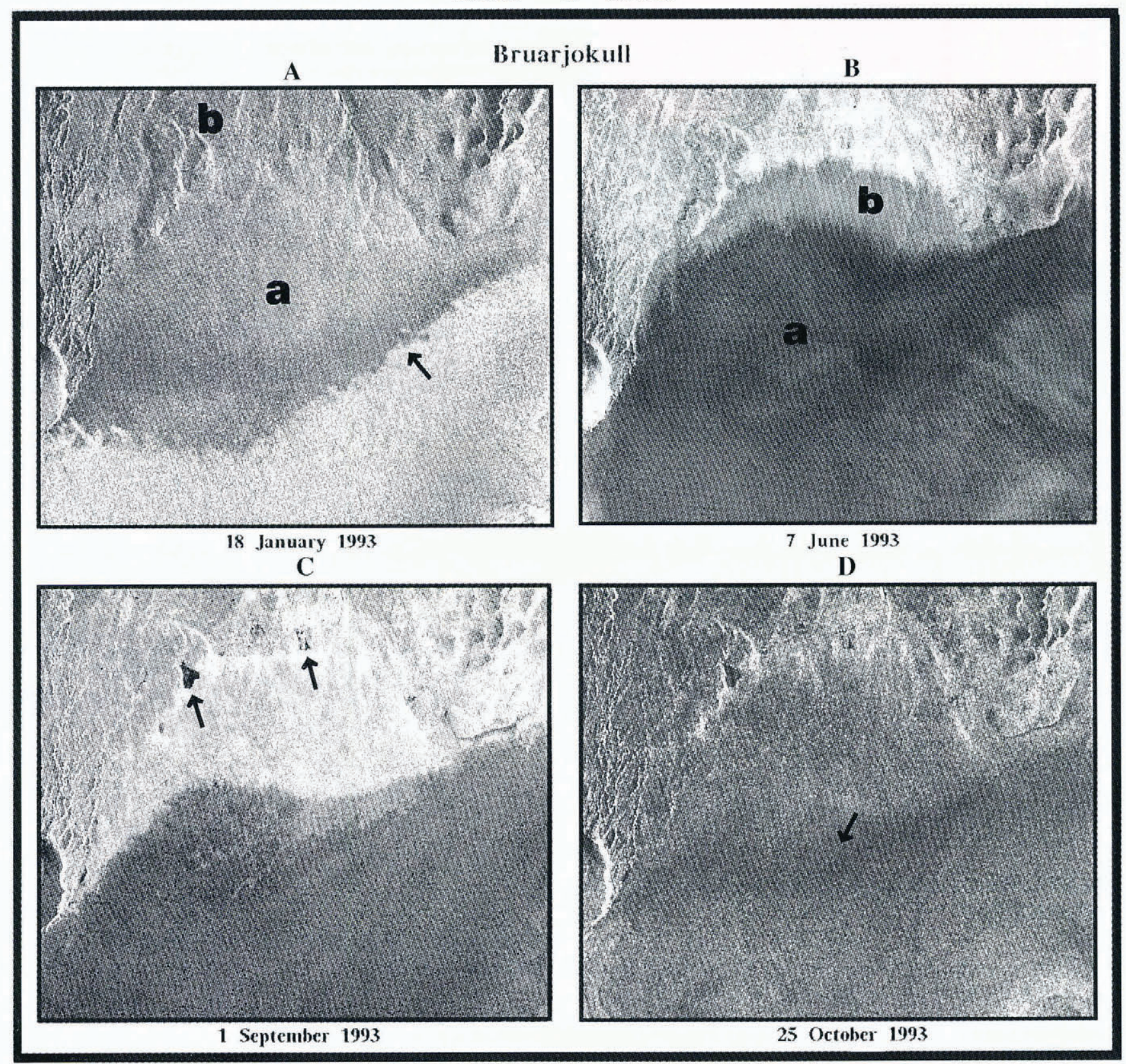

Fig. 3. Four 1993 ERS-1 SAR images of Bruarjökull acquired on (A) 18 January. (B) 7 June, (C) 1 September, and (D) 25 October. The individual images are digitally registered with the Landsat image (Fig. 2) and thus the scale and orientation are the same. A. The arrow points to a boundary delineating different back-scatter intensities; $a$ is in an area of snow-covered glacier ice, and $b$ is in an area beyond the glacier terminus representing deglaciated lerrain. $B . a$ is in an area on the glacier that probably has begun to melt, at least on the surface, and thus gives a lower back-scatter, and $b$ is an area of the terminus with a higher back-scatter. C. The arrows point to ice-margin lakes. D. The arrow points to an area representing a transition in SAR back-scatter (see text). SAR data are copyrighted by ESA.

boundary corresponds almost perfectly to the firn limit visible on the 7 September 1991 Landsat TM image (see Fig. 2; position a) in the eastern and western parts of Brúarjökull. On the 7 June 1993 SAR image (Fig. 3B), the surface of Brúarjökull gives a generally low radar return $\left(\sigma^{\circ}=-20.17 \mathrm{~dB}\right)$ from an area that appears to be covered with snow that has begun to melt (see Fig. 3B; area a). The back-scatter increases (to $\sigma=-11.66 \mathrm{~dB}$ ) downglacier (see Fig. 3B; area b).

By 1 September 1993, ice-margin lakes (see arrows on Figure $3 \mathrm{C}$ ) along the terminus of Brúarjökull are unfrozen and give low back-scatter $\left(\sigma^{\circ}=-20.43 \mathrm{~dB}\right.$ on the largest lake). The lakes are thus easily distinguishable from the recently deglaciated terrain north of the outlet glacier where $\sigma^{\circ}=-8.28 \mathrm{~dB}$. On 18 January, when snow-covered and frozen, the ice-margin lakes have a back-scatter value $(2 \mathrm{~dB})$ similar to that of the deglaciated terrain $\left(\sigma^{\circ}=-7.04 \mathrm{~dB}\right)$ (see Fig. $3 \mathrm{~A}$; area b) and blend into both the terrain and the snow-covered glacier surface.

Surface topography and tephra layers are well depicted on the 25 October 1993 SAR data. They are visible on the digital data, but, unfortunately, because 
there is only a subtle back-scatter difference with the surrounding moraine, the surface expression of topography and tephra layers does not show up on the photographic product (Fig. 3D). Because the tephra layers are small, and there may not be 500 "pure" pixels with which to calculate a statistically valid $\sigma^{\circ}$, the backscatter was not calculated. The tephra layers correspond closely to the same layers on the 7 September 1991 Landsat TM scene (see Fig. 2; position b). Also on the October SAR image, there is a diffuse back-scatter boundary possibly at the firn line (see arrow).

The correspondence between the back-scatter boundary at the arrow on Figure $3 \mathrm{~A}$, and the firn-limit boundary shown on the 7 September 1991 Landsat TM image (see Fig. 2; position a) is good, except that there is some lack of correspondence in the central part of Brúarjökull. The equilibrium line on Brúarjökull at the end of the 1990 91 budget year was exceptionally high (at a higher elevation than the firn line) and exceptionally low in elevation in the 1991-92 and 1992 93 budget years. On the winter SAR image the snow-covered terminus see Fig. $3 \mathrm{~A}$; area a), had a back-scatter of $\sigma^{\circ}=-6.2 \mathrm{~dB}$, similar to the deglaciated terrain to the north (see Fig. 3A; area b); thus, the margin of the outlet glacier is not easily visible. The radar returns above the back-scatter boundary are higher $\left(\sigma^{\circ}=-2.53 \mathrm{~dB}\right)$, perhaps because the grain-sizes are larger in the firn of the accumulation area than in the new snow in the ablation area which is transparent or nearly transparent to the SAR signal.

Note on the 7 June 1993 SAR image (Fig. 3B the low radar return on the surface of Brúarjökull in area a $\left(\sigma^{\circ}=-20.17\right)$. At this time of year, this part of the glacier surface may be covered with water-saturated snow. The SAR signal is absorbed by water or wet snow, and there is no volume scattering. However, the glacier ice in the lower part of the glacier (see Fig. 3B; area b) gives a higher radar return $\left(\sigma^{\circ}=-11.67\right)$.

Ice-margin lakes are sometimes visible (see arrows in Figure $3 \mathrm{C}$ ) abutting the terminus of Brúarjökull. Icemargin lakes can be used to indicate the position of the terminus of the glacier, even if it is obscured by morainic debris or snowpack, because they form in front of and against the glacier or its terminal moraine. Summer TM and SAR scenes are often optimum for delineation of the glacier terminus because of the fact that ice-free, icemargin lakes are readily visible. The higher SAR returns that characterize the ice-margin lakes when they are frozen (Fig. 3A and B) are indicative of floating ice.

Surface undulations are apparent on the 25 October 1993 digital SAR data, but difficult to see on photographic products. Previous work has shown that surface undulations may be detected with both SAR data Molnia and Jones, 1989) and digitally enhanced Landsat data, especially low-solar-elevation Landsat data (Thorarinsson and others, 1974; Williams, 1987). The undulations seen in the October digital SAR data may be the surface expression of subglacial topography (Thorarinsson and others, 1974; Molnia and Jones, 1989).

\section{DISCUSSION AND CONGLUSIONS}

Analysis of ERS-1 SAR data from four different seasons in
1993 of the Brúarjökull outlet glacier reveals the existence of SAR back-scatter boundaries that probably relate to glacier facies. A distinct back-scatter boundary on Brúarjökull recorded on the 18 January 1993 SAR image appears to coincide closely with the position of the transient snow line at the end of the 1990 91 budget year (see 7 September 1991 Landsat TM image). At the end of the 1991-92 and 1992 93 budget years, the equilibrium line was at a much lower elevation on the glacier than in the 1990-91 budget year. This observation supports observations made by other scientists that the firn line may be visible on SAR images when it is overlain by dry, winter snow (Lingle and others, 1992). In the case of Brúarjökull, a snow line may be visible through both winter snow and 2 year-old firn. Additional work will be done on 1991 and 1992 ERS-1 SAR images to test this hypothesis.

Several factors contribute to the difficulty in delineating the precise boundary of the terminus on both SAR and TM data of some glaciers and ice caps during certain times of the year. Supraglacial morainic, wind-blown and water-deposited sediment on the surface of Brúarjökull obscures the surface below the snow line. This sediment formed because the outlet glacier has been in a stagnant, melt-back, and down-wasting condition since its $8 \mathrm{~km}$ surge 30 years ago. Additionally, the similarity of surface topography of the glacier and the nearby deglaciated terrain contributes to the difficulty of delineating the terminus. However, ice-margin lakes show up well on the 1 September 1993 SAR and the 7 September 1991 TM images, and clearly indicate the position of the terminus at those lakes.

The use of Landsat TM and ERS-1 SAR provides much information about glaciological features, including glacier-surface and near-surface features. This is especially evident when images from different seasons are available for analysis.

\section{ACKNOWLEDGEMENTS}

We would like to thank G. Linebaugh of Hughes STX, Greenbelt, MD, and J. Chien of GSC, Laurel, MD, for image processing of the Landsat and SAR data.

\section{REFERENCES}

Benson, C.S. 1962. Stratigraphic studies in the snow and firn of the Greenland ice sheet. SIPRE Res. Rep. 70.

Bindschadler, R. A., K. C. Jezek and J. Crawford. 1987. Glaciological investigations using the synthetic aperture radar imaging system. Ann. Glaciol., 9. 11-19.

ESA. 1993. ERS-1 user handbook. Paris, European Space Agency. (ESA $\mathrm{SP}-1148$, revision 1.

Fahnestock, M., R. Bindschadler, R. Kwok and K. Jezek. 1993. Greenland ice sheet surface properties and ice dynamics from ERS-1 SAR imagery. Science, 262 (5139), 1530-1534.

Ford, J. P. and 6 others. 1980. Seasat views North America, the Caribbean, and western Europe with imaging radar. Pasadena, CA, California Institute of Technology. Jet Propulsion Laboratory. (JPL Publication 80-67.)

Haeberli. W., P. Müller, J. Alean and H. Bösch. 1989. Glacier changes following the Little Ice Age a survey of the international data basis and its perspectives. In Oerlemans, J., ed. Proceedings of the Symposium on Glacier Fluctuations and Climatic Change, held in Amsterdam, 1-5 June 1987. Dordrecht, etc., Kluwer Academic Publishers, 77-101.

Hall, D. K. and J. P. Ormsby. 1983. Use of SEASAT synthetic aperture radar and LANDSAT multispectral scanner subsystem data for 
Alaskan glaciology studies. 7. Geophys. Res., 88 C3), 1597-1607.

Hall, D. K., R. S. Williams, Jr and K.J. Bayr. 1992. Glacier recession in Iceland and Austria as observed from space. EOS, 73 12, 129, 135, 141.

Hunting Geology and Geophysics, Ltd. No date. Seasat-1 radar mosaic of Iceland. 1:500,000-scale mosaic constructed by Hunting Surveys, Lid., Borehamwood, Hertfordshire, England, for the Royal Aircraft Establishment. Borehamwood, Hertfordshire, Hunting Geology and Geophysics, Ltd. (European Space Agency-Earthnet.

Laur. H. 1992. ERS-1 SAR calibration, derivation of backscattering coefficient $\sigma^{\circ}$ in ERS-1.SAR.PR I products, Issue 1, Rev., October 1992.

Lingle, C., W. D. Harrison and K. Ahlnaes. 1992. Observations of glaciers in the St. Elias Mountains, Alaska Yukon Territory, with synthetic aperture radar. American Association for the Advancement of Science. 43rd Arctic Science Conference. Program and proceedings. Environmental change: natural and man-made. September 8-12, 1992, Valdez, Alaska. Fairbanks, University of Alaska. Geophysical Institute, 37.

Meier, M.F. 1984. Contribution of small glaciers to global sea level. Science, 226 (4681), 1418-1421.

Meier, M.F. 1985. Mass balance of the glaciers and small ice caps of the world. In United States Department of Energy. Glaciers, Ice Sheets, and Sea Level: Effect of a $\mathrm{CO}$-Induced Climatic Change. Report of a Workshop held in Sealle, Washington, September 13-15, 1984. Washington, DC, National Academy Press, 139-144.

Molnia, B. F. and J. E. Jones. 1989. View through ice. EOS, 70 28), 701, 710.

Oerlemans, J. 1994. Quantifying global warming from the retreat of glaciers. Science, 264(5136), 243-245.
Rott, H. 1984a. Synthetic aperture radar capabilities for snow and glacier monitoring. Adv. Space Res., 4(11), 241-246.

Rott. H. 1984b. The analysis of backscattering properties from SAR data of mountain regions. IEEE J. Ocean Eng., OE-9(5), 347-355.

Sigurdsson, O. and T. Jónsson. 1995. Relation of glacier variations to climate changes in Iceland. Ann. Glaciol., 21, (see paper in this volume).

Thorarinsson, S. 1964. Sudden advance of Vatnajökull outlet glaciers 1930-1964. Jökull, 14, 76-89.

Thorarinsson, S., K. Sæmundsson and R. S. Williams, Jr. 1974. ERTS-1 image of Vatnajökull: analysis of glaciological, structural, and volcanic features. Jökull, 23, 1973, 7-17.

Todtmann, E. M. 1960. Gletscherforschungen auf Island (Vatnajokull). Hamburg, Cram, de Gruyter and Company. (Universität Hamburg. Abhandlungen aus dem Gebiet der Auslandskunde, Bd. 65Reihe C (Naturwissenschaften), Bd. 19.

Williams, R. S., Jr. 1983. Satellite glaciology of Iceland. Jökull, 33, 3-12.

Williams, R.S., Jr. 1987. Satellite remote sensing of Vatnajökull, Iceland. Ann. Glaciol., 9, 127-135.

Williams, R. S.. Jr and 8 others. 1974. Environmental studies of Iceland with ERTS-1 imagery. In Proceedings of the Ninth International Symposium on Remole Sensing of Environment, 15-19 April 1974. Volume 1. Ann Arbor, MI, Environmental Research Institute of Michigan, 31-81.

Williams, R. S., Jr, D. K. Hall and C. S. Benson. 1991. Analysis of glacier facies using satellite techniques. J. Glaciol., 37(125), 120-128.

Wood, F. B. 1988. Global alpine glacier trends, 1960s to 1980s. Arct. Alp. Res., 20 (4), 404-413. 